together with the ossicles and remains of the membrana tympani. The cavity was thoroughly wiped over with a 1 in 20 carbolic solution, espocial care being taken to avoid further injury to the facial nerve. The cartilaginous meatus was split up to the concha and the two halres were pressed back on the raw bony surfaces with gauze packing. The wound was sewn up without drainage and the usual antiseptic dressings were applied. The child passed a good night and his temperature remained normal until the following night when it rose to $101^{\circ}$. On removing the dressing I found it necessary to take out a stitch and to introduce a gauze drain. There was a discharge of pus both from the ear and the wound for about three weeks, but at the end of that time it had entirely ceased. 24 hours after operation it was noticed that the child could close his right eye and from that date onwards rapid improvement in the facial paralysis took place, until, on his ledving the hospital on March 4 th, all trace of it had disappeared.

Remarks. - This case is of interest from the fact of the early and complete restoration of function in the facial nerve, indicating, as it does, that too much time should not be wasted in non-operative treatment, for the prospect of a successful result is poor and permanent facial paralysis is practically certain.

Staveley, Chesterfield.

\section{A NOTE UPON THE SUTURE OF INCISIONS OF THE ABDOMINAL WALL IN LAYERS WITHOUT BURIED SUTURES.}

By J. B. PIKE, M.R.C.S. ENG., HONORARY SURGEON TO THE IOUGHBOROUGH HOSPITAI.

THE occasional persistence of troublesome sinuses after the union of the deeper structures of the abdominal wall by buried sutures suggested to $\mathrm{my}$ mind that the desired end might possibly be obtained without the risk of that complication. The method by which I have tried to accomplish this is as follows. The peritoneum having been closed by catgut

FIG. 1.

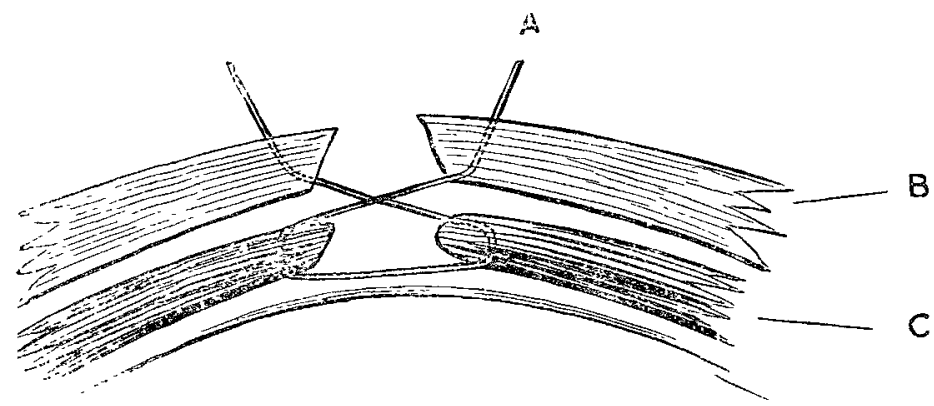

Suture inserted. A. Suture B, Integument. C, Muscle, \&c. Peritoneum. E, Superticial loop. F, Deep loop.

FIG. 2.

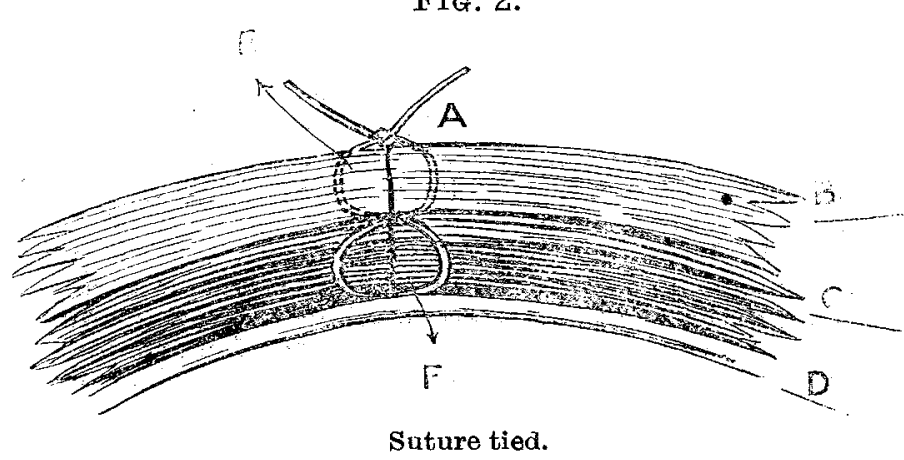

suture a somewhat curved needle is armed with silkworm gut and passed through the skin and subcutaneous tissues; it is then carried through the muscles of the opposite side, back again through the opposing muscle layer, and finally through the skin tissue on the other side of the incision from the primary puncture (Figs. 1 and 2). In this way a figureof-eight. loop is formed, the deeper segment inclosing the muscular layer and the more superficial the skin. The suture may also be readily passed by means of a thread with a needle at both ends. In that case the muscle layer is transfixed on both sides from within outward and the skin is punctured after crossing the suture to form the deep loop. The peritoneum can be included in the deep loop if thought desirable. By this method the edges of the incised skin are brought well together and the effect in approximating the muscular layers can be judged by outward traction on the free ends of the suture before tying.

The theory of this method seemed to me satisfactory. I therefore tried it in two cases operated upon by my colleague, Mr. R. B. Stamford. The first was a case of septic peritonitis; the incision was central. On account of the patient's condition a rapid closure was desirable. The wound was closed by sutures passed through the whole thickness except the lower part. This was packed with gauze and above the gauze I inserted two figure-of-eight sutures. All the sutures became more or less septic, so this test was not a good one except that one could see that the two lowest sutures brought the skin together more evenly and that on removing the gauze the muscle could be seen to be approximated. The second case was one of incision in the iliac region for removal of the appendix. Mr. Stamford sewed the peritoneam with continuous catgut and inserted double loop sutures according to my suggestion. Two stitches were removed on the tenth day and I removed the rest on the fourteenth. They came away with moderate traction and without much inconvenience to the patient. The length of the loop showed that a good thickness of tissue was included and the appearance of the wound was all that could be desired.

I hope this method may be tried and have a useful future. The end which it seems adapted to obtain is certainly desirable.

Loughborough.

\section{A CASE OF EPIBULBAR SARCOMA.}

\section{BY JoHN Robert Foster, M.B. Edin., F.R.C.S. EdiN.}

THE recently published (1904) Part I , vol. i., of "Herbert Parsons's Pathology" contains the following short paragraph on the subject of epibulbar sarcoma: "The general opinion as to malignancy is voiced by Strouse, who says that epibulbar sarcomata never penetrate the globe and rarely produce metastases. Verhoeff and Loring regard them as highly malignant, judging by their tendency to recur and to form metastases."

This paragraph recalled to my mind a case which was under my care in 1904 and which deserves to be recorded in view of the diversity of opinion on this important subject. The patient, who was a boy, four years of age, was sent to me in October, 1904, by Dr. W. Ross of West Hartlepool for consultation. He had on the outer side of the right eyeball in the inter-palpebral region a small dark growth, slightly raised about the conjunctiva, roughly circular, about four millimetres in diameter, and freely moveable on the eyeball. The mother volunteered the statement that the growth had been there since birth but had recently markedly increased in size; this latter was the reason she had consulted her general medical adviser. The result of the consultation was that operation was advised and a couple of days afterwards chloroform was administered and the growth was removed freely. All went well until February, 1905 , five months later, when the patient was again brought to me with a small red nodule situated a little below the site of the original growth, more circumscribed and more raised and considerably smaller than the primary growth; it was still moveable over the eyeball. We sent the case to Dr. A. S. Percival of Newcastle-on-Tyne for consultation. Conservative methods were recommended. Accordingly, in February, 1905, Dr. Ross again kindly administered chloroform and I freely removed the nodule, laying bare an area of sclera which could scarcely be covered by the end of the finger. At the present time (13 montbs since this second operation) the boy is strong and well, with no sign either locally or generally of the old trouble. Mr. Elmore W. Brewerton kindly made sections of both tumours and supplied the following report.

Report of Mr. BREWERTON.-Primary tumour. The tumour consists of a small nodule with some outlying processes, 
covered by a few flattened epithelial cells and resting on the submucosa of the conjunctiva, which latter shows no evidence of infiltration. The cells of the nodule are arranged in large alveoli and are mostly small with a large nucleus. At the centro of each alveolus are some large epithelial cells. The tumour is non-pigmented and contains it few small blood-vessels resembling capillaries. Diagnosis: The tumour is no doubt a congenital mole. Recurrent growth. The tissue consists of the whole thickness of the conjunctiva, in the deeper tissues of which is a small round nodule. This nodule consists of cells resembling the smaller cells of the primary tumour. The nodule is not encapsulated and in one portion the cells are infiltrating the surrounding tissues. The conjunctiva is more vascular than usual. There are no definite blood-vessels in the nodule. Diagnosis: The tumour now is undoubtedly sarcomatous.

Unquestionably these reports show the tumour to have been an alveolar sarcoma, for although the primary growth microscopically is described as a mole it was no doubt clinically becoming a sarcoma-at least, the rapid increase in size noticed by the mother indicates this in all probability. West Hartlepool.

\section{A dutirnor}

\section{HOSPITAL PRACTIOE。 BRITISH AND FOREIGN.}

Nulla autem est alia pro certo noscendi via, nisi quamplurimas e morborum et dissectionum historias, tum aliorum tum propria collectas habere, et inter se comparare.-MorgagNI De Sed.et Caus. Morb., lib. iv., Proœmium.

\section{ROYAL EAR HOSPITAL, SOHO.}

A CASE OF CHRONIC SUPPURATIVE OTITIS MEDIA WITH CHOLESTEATOMA ; RADICAI MASTOID OPERATION ; COM -

PLICATIONS ; HERNIA CEREBRI ; TEMPOROSPHENOIDAL ABSCESS ; MIANTACAL DELI. RICH OF LONG DURATION; RECOYERY.

(Under the care of Mr. MACLEOD YEARSLEY.)

FoR the notes of the case we are indebted to Mr. J. Arnold Jones, house surgeon.

A youth, age 18 years, was first seen by Mr. Yearsley at the Rosal Ear Hospital on Sept. 27th, 1905. The patient was suffering trom a chronic discharge from the left ear of about five months' duration. He was sent by Mr. J. Blackwood of Southsea, under whose care he had been for some time and who some three weeks previously had removed polypoid tissue from the meatus. On examination a perforation was seen in the anterior part of Shrapnell's membrane through which a fotid discharge issued. The watch could not be heard at all by the left ear and the tuning fork showed Rinné negative with bone conduction diminished by eight seconds. The patient complained of slight vertigo and vertical headache.

A thorough course of irrigation with perchloride solution (1 in 2000) and the instillation of hydrogen peroxide was the line of treatment at first adopted, but no improvement ensuing it was decided to perform the complete post-aural operation. This was done on Nov. 9th by $\mathbf{M r}$. Yearsley, assisted by $\mathrm{Mr}$. A. Logan Murison, chloroform being administered by Mr. J. H. Chaldecott. The usual incision was made, the upper and posterior portions of the cartilaginous were separated from the bony meatus, and the whole ear was turned forwards. The antrum was then approached with a hand gouge and discovered to be murh dilated and tull of foul cholesteatomatous masses. There was a large hole, something under the size of a threepennypiece, in the tegmen antri with a ragged tear in the dura mater through which a small knuckle of congested brain protruded. The "bridge" of bone between the antrum and the tympanic cavity was removed, a Körner's flap was cut in the cirtilaginous meatus, the cavity was packed with gauze, the incision was sewn up, and the usual dressings were applied.

During the next three days the patient appeared to be comtortable and doing well, still, however, exhibiting a certain childishness or simplicity of manner which had been noted on his admission. The temperature, which was $99^{\circ} \mathrm{F}$ on admission, oscillated between that and $99 \cdot 6^{\circ}$. The pulse was 84 , regular, and strong. On Nov. 13th the temperature became $101 \cdot 4^{\circ}$ and the first dressing was done. The post. aural wound was sound but there was a rather foul discharge from the meatus. Hydrogen peroxide was instilled and the cavity was syringed through the meatus with perchloride solution. On the 14 th the temperature was normal; the wound was again dressed, the discharge being about the same. The general condition of the patient was quite good. The dressing was now done every day in the same manner the discharge persisted, the temperature varying from normal to $100 \cdot 6^{\circ}$. On the 18th, in the evening, the temperature reached $102^{\circ}$. The patient cornplained of headache and cold feet. The pulse was 84 , strong, and regular. There were no ocular or other localising symptoms. On the 19 th the temperature remained high and the dressing was very foul, the headache became worse, and the patient began to be restless. On the 20 th the temperature at 11 A.M. was $102 \cdot 8^{\circ}$. The patient had developed pains in the neck and back, the head. ache persisted, but the discharge, although still free, was sweeter in character. The tongue was very furred in spite of good action of the bowels resulting from aperients. The general appearance was quite good. There were no localising symptoms. The pulse was 92, strong, and full. He was ordered ten grains of calomel. On the 21st the patient seemed to be somewhat better. He was not so restless and the pains in the neck and back were less. The dressing was comparatively sweet but not so free. The temperature was $101^{\circ}$. Towards 8 P.M., however, he became much more restless. He did not respond very readily to questions and began to cry ont loudly and frequently. 40 grains of potassium bromide having no effect five minims of morphine were ordered to be injected, but this and a further three minims only procured two hours' sleep.

On Nov. 22nd the patient appeared to be worse. $\mathrm{He}$ was more emaciated, his mouth was dry and ulcerated, and his tongue was very furred, although the bowels were freely acting. The pulse was 92 , full, and strong. The tempera ture was $102 \cdot 2^{\circ}$. At frequent intervals he uttered a curious animal cry; there were no localising symptoms of any kind. $H$ is knees were drawn up and the muscles of the legs were rigid. He apparently recognised no one and took no notice when spoken to. $\mathrm{He}$ was seen by $\mathrm{Mr}$. Yearsley and $\mathrm{Mr}$. R. Lake in consultation and further operation was decided upon This was done the same afternoon by Mr. Yearsley, assisted by Mr. Lake and Mr. R. S. Cocke. Chloroform was adminis tered by Mr. Chaldecott. The wound was reopened and the antrum was found to be filled by a gangrenous hernia cerebri. This was shaved off and a quantity of foul pus escaped. An abscess in the temporo-sphenoidal lobe was discovered of about the size of a walnut; this was evacuated and washed out. A large double drainage-tube was inserted. The post-aural wound was left open and the usual dressings were applied. After the operation the temperature at 6 P.M. registered $100 \cdot 5^{\circ}$ and the patient remained quiet until about 7 P.M., when he once more became very restless and more boisterous than ever; an injection of morphine (one-quarter of a grain) was given which, with one drachm of potassium bromide, kept him fairly quiet until 7 A.M. on the $23 \mathrm{rd}$ when he became uncontrollably noisy. The morphine (one-quarter of a grain) was repeated and again his delirium was held in check. At 2.15 P.M. he was dressed under ethyl chloride anæsthesia administered by Mr. Chaldecott. The tubes were irrigated with boric lotion but, with the exception of some organised clot, very little discharge came away. The temperature at 6 P.M. was $99^{\circ}$, the pulse was 92 , and the respirations were 20 . The patient again becoming very restless one drachm of potas sium bromide every hour until be was quiet was ordered, but this having little effect after six drachms had been administered, an injection of a quarter of a grain of morphine was given and repeated in three and a half hours. In spite of these hypnotics only three hours' rest were obtained during the night, the remainder of the time being spent in tossing about the bed, shouting at intervals his curious piercing cry. The patient all this time took large quantities of nourish. ment in the form of whey and beef-tea, consuming in the 24 hours 35 ounces of the former and 13 ounces of the latter.

On Nov. 24th the patient slept all the morning, with the exception of an hour. At 2 P.M the wound was again dressed in the same manner as the previous day; it was in the same condition. The temperature varied from $99^{\circ}$ in the morning to $101 \cdot 2^{\circ}$ at night. 30 grains of chloralamide, 